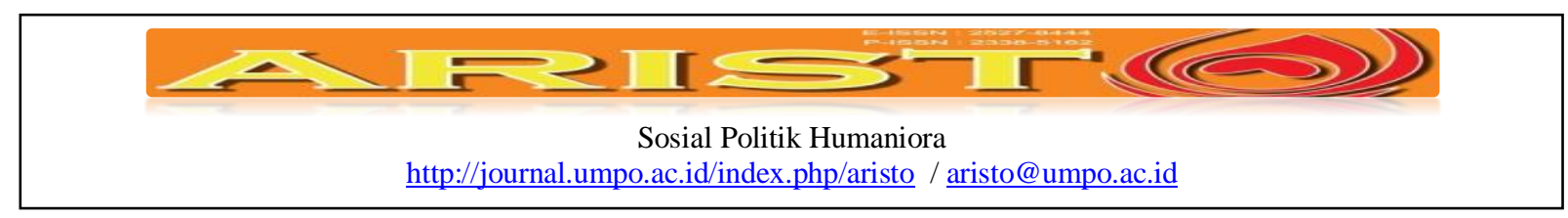

\title{
Keterlibatan Kaum Bangsawan dalam Pemilihan Kepala Daerah (Pilkada) di Kabupaten Pinrang Provinsi Sulawesi Selatan
}

\author{
Muchlas M.Tahir, Fitriani Sari Handayani Razak, dan Zulfan Nahruddin. \\ Program Studi Ilmu Pemerintahan,FISIP, Universitas Muhammadiyah Makassar. \\ muchlas@unismuh.ac.id, fitriani90@ymail.com \& zulfannahruddin@gmail.com
}

\begin{abstract}
Pilkada became a space that presents the elite of the community, but behind the contestation of the phenomenon is quite interesting when people are faced with a dilemma where the elite who compete are the descendants of nobility. This study used a qualitative approach to explainingd main problems discussed by descriptive method. The fact is Strang Bugis society community, always have a desire to domination power and not hesitate to mutually contest between the group. The fact that Andi's group who contested in the arena of elections is inseparable from these three things: First, the building construction of the Andi's behavior in the society structure becomes the determinant to get the voters sympathy. Second, look at the capital in the Andis as a means to contest the winner, the capital's most powerful capital and also in the sense of being. Third, the habitus and capital will affect Andi's victory in which the arena of Pilkada as a container or to play the habitus and capital. These three things became the determinant of the winning process of the actor who was contesting in the arena of elections.
\end{abstract}

Keyword: Involvement, Aristocracy, Local Politics.

\begin{abstract}
Abstraksi
Pilkada menjadi ruang yang menyajikan keterlibatan para elit masyarakat, namun dibalik kontestasi tersebut fenomena cukup menarik ketika masyarakat dihadapkan pada dilematik dimana para elit yang berkompetisiadalah keturunan bangsawan.Penelitian ini menggunakan pendekatan kualitatif untuk menjelaskan secara metode deskriptif permasalahan pokok yang dibahas. Fakta yang adasebagai golongan strata atas masyarakat Bugis, bangsawan senantiasa memiliki hasrat untuk menodminasi kekuasaan dan tidak segan-segan saling berkontestasi antar kelompoknya.Fakta bahwa golongan Andi yang berkontestasi di arena kuasa yakni secara spesifik pilkada tidak terlepas dari tiga hal yakni: Pertama, bangunan kontruksi tingkah laku para Andi dalam struktur masyarakat menjadi penentu untuk mendapatkan simpati pemilih. Kedua, kehadiran modal dalam diri para Andi menjadi alat untuk berkontestasi menjadi penentu kemenangan, modal yang paling kuat yakni modal simbolik serta dominasinya dalam masyarakat berpengaruh terhadap dukungan yang diperoleh.Ketiga, habitus dan modal akan mempengaruhi kemenangan Andi dimana arena Pilkada sebagai wadah pemanfaatan atau mempermainkan habitus dan modal tersebut.Ketiga hal ini menjadi penentu proses kemenangan sang aktor yang tengah berkontestasi di arena pilkada.
\end{abstract}

Kata Kunci: Keterlibatan, Kaum Bangsawan, Politik Lokal

$\begin{array}{ll}\text { Submite } & : \text { 14 Nov } 2016 \\ \text { Review } & : \text { 14 Nov } 2016 \\ \text { Accepted } & : \text { 01 Jan } 2017 \\ \text { Surel Corespondensi } & : \text { jovani.audra@gmail.com / adamhilman@umpo.ac.id }\end{array}$

Muchlas M.Tahir, Fitriani Sari Handayani Razak, dan Zulfan Nahruddin / Public Policy /9/Vol. 5.No. 1. Tahun 2017 


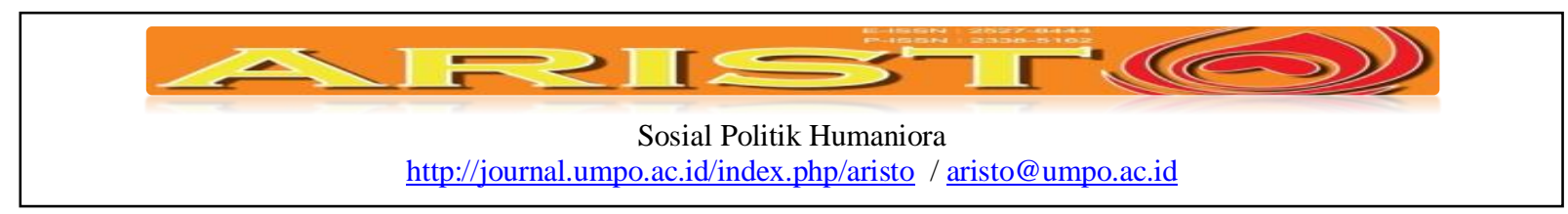

Pendahuluan

Partisipasi politik secara harafiah berarti keikutsertaan, dalam kontekspolitik hal ini mengacu pada pada keikutsertaan warga dalam berbagai proses politik. Keikutsertaan warga dalam proses politik tidaklah hanya berarti warga mendukung keputusan atau kebijakan yang telah digariskan oleh para pemimpinnya, karena kalau ini yang terjadi maka istilah yang tepat adalah mobilisasi politik. Partisipasi politik adalah keterlibatan warga dalam segala tahapan kebijakan, mulai dari sejak pembuatan keputusan sampai dengan penilaian keputusan, termasuk juga peluang untuk ikut serta dalam pelaksanaan keputusan (Muhiddin, 2015).

Demokrasi serta hadirnya liberalisasi politik dimanfaatkan semua golongan atau kelompok masyarakat tampil dalam panggung politik untuk menunjukkan kekuatan mereka. Pada masa Orde Baru ini tidak banyak golongan bangsawan di Indonesia yang mampu menunjukkan power mereka agar tetap survive dalam mengatur wilayah kekuasaannya. Kajian tentang bangkitnya para bangsawan dalam mendapatkan kekuasaan di tingkat lokal telah menjadi kajian yang makin menarik dan menantang, hal ini disebabkan karena di setiap daerah di Indonesia memiliki komunitas bangsawan yang tetap eksis dan memiliki strategi agar tetap survive dan mendapat kehormatan serta kekuasaan di kalangan masyarakat. Bangsawan di berbagai daerah memiliki historis yang menjadi simbol dan cerita yang terdoktrinisasi dari generasi ke generasi.Namun tidak banyak bangsawan yang mampu bertahan dengan kekuasaan tradisional dan identitas kedaerahan. Selain itu di era Orde Baru para pemangku adat daerah seakan tengah "tertidur" di balik sistem otoriter sang penguasa. Apalagi dewasa ini yang menuntut hadirnya good governance disegala lini termasuk dalam proses konstalasi politik seperti pilkada. Governance yang mengedepankan akomodasi, kooperasi dan sinergi dalam kesetaraan antar perilaku (Prianto, 2011).

Pasca runtuhnya rezim Orde Baru, para bangsawan kembali hadir menggali dan menunjukkan identitas mereka.Seperti yang dikemukakan oleh Gerry Van Klinken (2007, dalam Davidson dkk) yang menunjukkan kembalinya para sultan terjadi di Kalimantan Barat dan Maluku Utara.Bangsawan ini berusaha untuk menghidupkan kembali tata kehidupan yang bernuansa keraton di setiap daerah.Klinken menyatakan bahwa gerakan bangsawan ini membentuk kelompok dalam menunjukkan eksistensi mereka dalam perpolitikan.Kelompok ini hendak mempertahankan feodalisme dalam bingkai republikan di era otonomi daerah. 


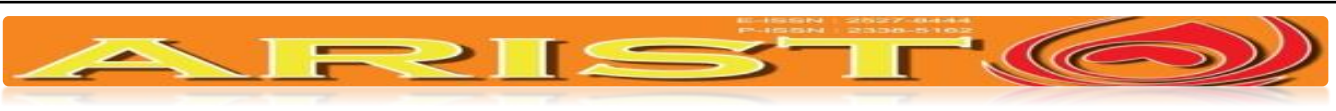

Sosial Politik Humaniora

http://journal.umpo.ac.id/index.php/aristo / aristo@umpo.ac.id

Senada dengan Ari Dwipayana (2004) yang mengeksplorasi feomena kembalinya kuasa kaum bangsawan di dua kota yakni Surakarta (Solo) dan Denpasar (Bali). Dengan menghadirkan genealogi kekuasaaan dari kaum bangsawan tersebut, serta strategi survive kaum bangsawan ini ditengah masa krisis yang pernah dialaminya, dan pasca tumbangnya rezim Soeharto bangsawan ini kembali eksis dan terjun kembali dalam arena kebudayaan, ekonomi, politik dan birokrasi.

Berdasarkan penelusuran sejarah di masa lalu, berbagai daerah di Indonesia terdiri dari kerajaan dan menganut sistem aristokrasi sebagai sistem yang tepat di masa lalu.Namun perubahan rezim dari masa ke masa memberikan pengaruh terhadap habitus para bangsawan.Terutama pada masa Orde Lama dan Orde Baru, kaum bangsawan ini dituntut untuk mengikuti pola dan sistem pemerintahan yang otoriter.Otoritarian penguasa Orde Baru tercermin dari berkuasanya para kroni-kroni Soeharto yang tersebar di ranah pemerintahan dan politik hingga ke tingkat lokal.Sebagai perpanjangan tangan pemerintahan pusat di daerah, jabatan bupati tentunya ditunjuk oleh pemeritah pusat dalam rangka mempertahankan kekuasaan Soeharto melalui jaringan di tingkat lokal.

Fenomena serupa terjadi di Sulawesi Selatan, Kabupaten Sengkang dimana terdapat pola kerja sama yang terjalin antara bangsawan dan penguasa masa Orde Baru. Tepatnya di Wajo para bangsawan yang mampu eksisdan survive di masa Orde Baru dikarenakan mereka mendekatkan diri dengan kekuasaan. Dengan cara masuk di partai golkar dan menjadi anggota militer, bangsawan di wajo dengan mudah menduduki jabatan di ranah politik dan pemerintahan (Andi Faisal Bakti, 2007 dalam Nordholt dan Klinken).

Pasca reformasi telah membuka ruang bagi semua kalangan masyarakat untuk berkontestasi di ranah politik termasuk pemilukada, tanpa melihat status yang ada. Walaupun bergulirnya otonomi daerah juga bukan semakin memperkuat komitmen pemerintah daerah untuk lebih memperhatikan masyarakat kelas bawah (Asiru,2011). Hal ini dimanfaatkan oleh bangsawan untuk mendapatkan kekuasaan agar tetap survive. Euforia demokrasi dirasakan hingga masyarakat daerah yang tercermin dari hadirnya para elit lama yang muncul dan siap berkontestasi di pemilukada.Eksistensi kaum bangsawan dalam wilayah politik pemerintahan tercermin banyaknya Andi yang menjabat pada posisi strategis dalam struktur pemerintahan dan 


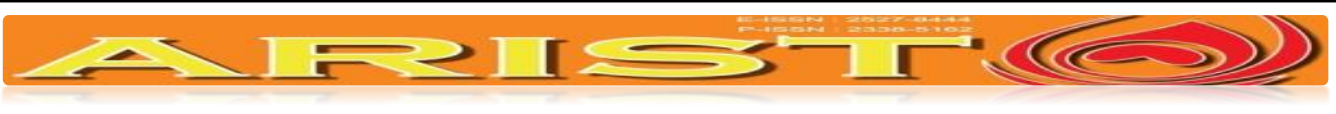

Sosial Politik Humaniora

http://journal.umpo.ac.id/index.php/aristo / aristo@umpo.ac.id

mendapatkan kedudukan di partai politik. Selain itu pasca runtuhnya masa Orde Baru elit lama (baca: bangsawan) kembali memimpin Pinrang ${ }^{1}$.

Momentum suksesi politik modern ini melibatkan masyarakat dalam proses pemilihan pemimpin di daerah, untuk itu ketiga pasangan kandidat ini memiliki strategis masing-masing dalam memobilisasi massa baik dalam internal keluarga mereka hingga masyarakat umum. Selain pasangan munculnya nama-nama baru (http://www. koran.tempo.co/konten/2013) pun telah beredar di berbagai media lokal dan kalangan masyarakat ${ }^{2}$. Sebagai pasangan incumbent tentunya Andi Aslam Patonangi masyarakat telah mengetahui serta merasakan karakter kepemimpinan Andi Aslam Patonangi ${ }^{3}$.Kemunculan para Andi yang berkontestasi di pemilukada dampak dari pemanfaatan liberalisasi politik, serta strategi mereka agar tetap survivedi kalangan masyarakat.

Kondisi ini secara tidak langsung mempertontonkan konflik elit baik dari sesama kaum bangsawan maupun konflik dengan kaum non bangsawan.konflik elit yang terjadi dalam Pemilukada, merupakan suatu fenomena politik lokal yang tidak bisa dihindari dalam setiap proses penyelenggaraan Pilkada. Konflik elit membawa implikasi positif dan negatif terhadap proses demokratisasi yang sedang praktekan di Indonesia dewasa ini(Nehrun, 2016).Harus diakui bahwa situasi politik ini memunculkan kedewasaan masyarakat dalam memilih yang terbaik dan sesuai dengan cita-cita masyarakat.Selain itu, harus dipahami bahwa desentralisasi dan demokratisasi lokal memiliki potensi besar untuk merangsang pertumbuhan organisasiorganisasi, serta jaringan masyarakat sipil (civil society) (Usman, 2011).Sehingga walaupun terjadi kontestasi yang didominasi oleh satu pihak, sesungguhnya itu menjadi jalan untuk menghadirkan jaringan masyarakat yang lebih kuat tanpa melihat status yang melekat pada diri

${ }^{1}$ Mengingat pasca Orde Baru yang menjadi bupati Pinrang adalah kalangan bangsawan yakni Drs. H.A. Masnawi A.S. periode 1998 s/d 1999, Drs. H.A. Nawir, MP tahun 1999-2009 (dua periode);dan H.A. Aslam Patonangi,SH,M.Si 2009-Hingga Sekarang. Hal ini membuktikan bangkitnya kaum bangsawan pasca rutuhnya Orde Baru, dan demokrasi telah membuka ruang bagi setiap orang untuk turut berpartisipasi baik sebagi pemilih dan yang dipilih dalam pemilu.

${ }^{2}$ Nama-nama yang muncul sebagai bakal calon bupati Pinrang yang beredar di berbagai media antara lain: Andi Irwan Hamid - A. Mappanyukki, A. Aslam Patonangi - Darwis Bastama, H. Abdullah Rasyid - H. Faizal Tahir Syarkawi, Suryadi Paroki - Sahabuddin Thoha, Kaharuddin Mahmud - Ardan Razak, dan Sulthani - Rifai Mana.

${ }^{3}$ Perjalanan karier Andi Aslam Patonangi berawal ketika menjadi sekretaris Camat di Watang Sawitto pada tahun 1996, kemudian menjadi Kasubid Pekerjaan Umum Bappeda tahun 2002, Camat Duampanua tahun 2005, Camat Watang Sawitto tahun 2006, dan saat ini tengah mejabat sebagai Bupati Pinrang. 


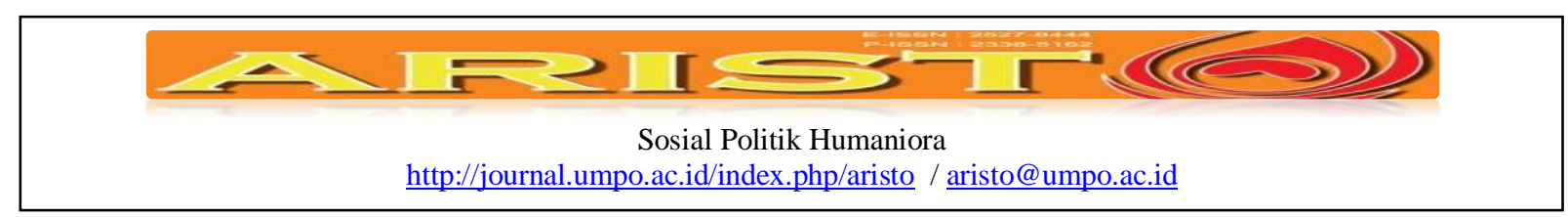

seseorang, melainkan kemampuan menyelesaikan masalah dan memberi kontribusi positif bagi masyarakat.

Kajian kebangkitan bangsawan telah lumrah dalam lingkup akademis, untuk itu dalam penelitian ini cenderung menyajikan kajian terkait kontestasi antar bangsawan itu sendiri.Pasca reformasi serta kehadiran liberalisasi politik kemudian membuka kesempatan bagi semua kalangan untuk berpartisipasi dalam politik modern mulai dari skala lokal hingga nasional, termasuk kontestasi para Andi dalam politik lokal yakni Pilkada.Pertarungan di arena Pilkada menjadi ajang yang menampilkan sumber daya (Demonstrate the Capital) para aktor lokal seperti bangsawan kepada masyarakat. Sumber daya tersebut merupakan modal yang dimiliki kemudian dikontruksi dalam memobilisasi massa sebagai alat untuk berkontestasi. Hal inilah yang hendak dikaji penulis, yang memfokuskan upaya para kandidat yang bergelar 'Andi' berkontestasi di pemilukada pada tanggal 18 september 2013.

\section{Kerangka Teori}

Dalam penulisan ini menggunakan kerangka teori yang dipelopori oleh Pierre Bourdieu yakni habitus, modal dan field digunakan untuk mengkerangkai telaahan ini.Konsep Habitus sendiri digunakan untuk melihat bagaimana kebiasaan para Andi sehingga dapat terjun dalam ranah politik khususnya mencalonkan diri dalam pilkada Kabupaten Pinrang. Habitus berasal dari bahasa latin yang mengacu pada kondisi, penampakan atau situasi yang tipikal atau habitual, khususnya pada tubuh (Richard Jenkis, 2004:107). Sebagai sesuatu yang tampak dari individu habitus cenderung mempraktikkan apa yang menjadi pemahamannya selama ini tentunya hal itu tidak terlepas dari sejarah dan pengetahuan individu.

Sejarah mengukir habitus para agen yang dibentuk oleh pengalaman dan pengajaran secara eksplisit sebagai sesuatu hal yang dapat diterima apa adanya. Karena hal ini merupakan proses produksi, penyesuaian dan hubungan dialektis antara habitus individu dalam suatu konsep sejarah secara kolektivitas yang berlanjut secara terus menerus mengikuti pola zaman sebagai ruang dan waktu. Untuk itu secara formal Bourdieu mendefinisikan habitus sebagai:

"Sistem disposisi yang bertahan lama dan bisa dialihpindahkan (transposable), struktur yang distrukturkan yang diasumsikan befungsi sebagai penstruktur struktur-struktur (structured structures predisposed to function as structuring structures), yaitu sebagai prinsip-prinsip yang melahirkan dan mengorganisasikan praktik-praktik dan representasi- 


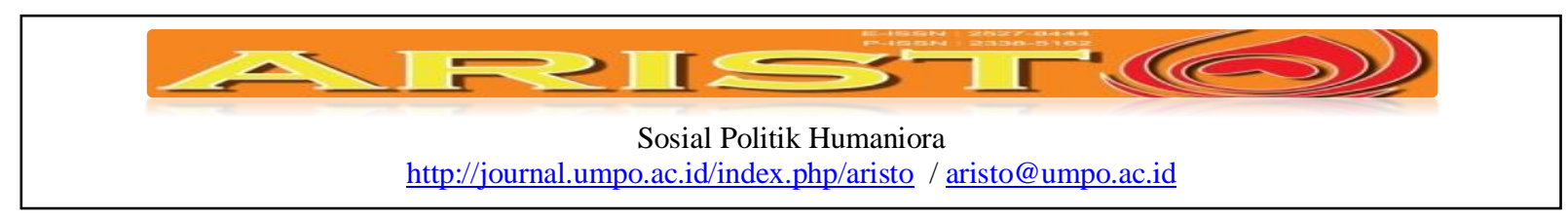

representasi yang bisa diadaptasikan secara objektif kepada hasil-hasilnya tanpa mengandaikan suatu upaya sadar mencapai tujuan-tujuan tertentu atau penguasaan cepat atas cara dan operasi yang diperlukan untuk mencapainya. Karena sifatnya 'teratur' dan 'berkala' secara objektif, tapi bukan produk kepatuhan terhadap aturan-aturan, prinsipprinsip ini bisa disatupadukan secara kolektif tanpa harus menjadi produk tindakan pengorganisasian seorang pelaku"

Selanjutnya field atau arena bertujuan untuk mengungkapkan ranah atau tempat para Andi pada fase awal sebelum tampil dalam panggung politik (Baca: Pilkada). Konsep arena merupakan konsep yang dinamis di mana perubahahan posisi agen berimplikasi pada perubahan struktur arena. Dalam arena apapun agen-agen yang menempati berbagai macam posisi yang tersedi atau menciptakan posisi-posisi baru akan terlibat dalam kompetisi yang memperebutkan kontrol kepentingan atau sumber daya dalam arena bersangkutan. Kampanye merupakan salah satu strategi arena yang digunakaan para aktor/elit untuk mendapatkan dukungan rakyat sebagi proses menuju kursi kepemimpinan dalam panggung politik. Lebih lanjut, Bourdieu dalam tulisannya yang kemudian diterjemahkan oleh Pipit Maizer (2009) menjelaskan tiga langkah dalam proses menganalisis suatu medan sebagai berikut:

"Pertama mencerminkan keunggulan medan kekuasaan ialah melacak hubungan setiap medan spesifik ke medan politis. Kedua memetakan struktur objektif relasi-relasi antar posisi-posisi yang ada di dalam medan itu. Ketiga menentukan hakikat habitus para agen yang menduduki aneka tipe posisi di dalam medan itu".

Panggung politik senantiasa menjadi arena yang sangat sengit yang dipenuhi pertunjukan seni mempengaruhi orang lain untuk mewujudkan kepentingan para aktor/elit yang bermain dalam panggung politik tersebut. Panggung politik ini notabene adalah pesta pemilukada (pemilihan umum kepala daerah) yang terjadi di Kabupaten Pinrang membuka arena pertarungan antar aktor/elit dalam mendapatkan kekuasaan. Selanjutnya capital atau modal yang dimaksudkan berupa sumber daya yang digunakan oleh Andi dalam berkompetisi.Menurut Bourdieo (dalam George Ritzer' 2011:908) terdapat empat tipe modal (capital) terebut yakni: (1) Kapital Ekonomi dimana seseorang harus memiliki harta benda, uang, kepemilikan dan sebagainya. Dalam konteks penelitian ini kapital ekonomi dilihat dari kepemilikan harta benda para Andi ini, termasuk kepemilikan harta benda, penguasaan akan tanah atau sawah serta perkebunan lainnya.(2) Kapital budaya/kultural terdiri dari bagaimana seseorang memanfaatkan informasi mengenai bentuk-bentuk kebudayaan, pengetahuan, memiliki strata pendidikan dan 


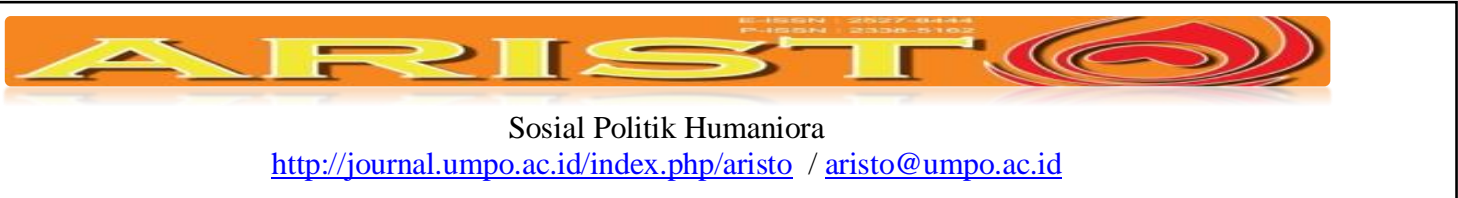

keterampilan. (3) Kapital simbolik ini berasal dari kehormatan yang didapatkan dari garis keturunan misalnya para darah biru atau bangsawan, modal simbolik ini mendapatkan tempat dan perhatian khusus di masyarakat sekitar karena memiliki perbedaan dari masyarakat lainnya. (4) Kapital sosial dapat dilihat bagaimana para aktor/elit ini membangun relasi-relasi dengan masyarakat tanpa ada sekat yang tentunya dapat dinilai orang sekitarnya serta mendapatkan penghargaan tertentu karena dapat membangun relasi sosial dengan baik. Kerangka teori tersebut digunakan sebagai benang merah dalam menemukan jawaban atas permasalahan yang diajukan dalam rumusan masalah dan berdasarkan pada fokus kajian penelitian.

Penelitian ini adalah pendekatan kualitatif. Penelitian ini juga menggunakan studi literatur, studi literatur adalah cara yang dipakai untuk menghimpun data-data atau sumbersumber yang berhubungan dengan topik yang diangkat dalam suatu penelitian. Studi literatur bisa didapat dari berbagai sumber, jurnal, buku dokumentasi, internet dan pustaka. Jenis data yang digunakan penulis dalam penelitian ini adalah data primer dengan melakukan wawancara dan observasi selama dua bulan yaitu pada bulan Agustus dan September 2016 dengan sejumlah informan Seperti Anggota KPUD Pinrang dan Kader Partai Demokrat serta tokoh masyarakat lainnya (yang bersifat purposive sampling). Kemudian penelitian ini juga menggunakan data sekunder yaitu data yang diperoleh dari jurnal, buku dokumentasi, dan internet.

\section{Hasil dan Pembahasan}

Pertarungan para Andi di arena pilkada semakin menunjukkan adanya ketidaksolidaritasnya ikatan komunitas Andi ini dalam meraih kekuasaan.Tak dapat dipungkiri adanya kontestasi yang tak terelakkan ketika berhadapan arena politik dalam memperebutkan kekuasaan.Ikatan kekerabatan yang dibangun ataupun komunitas yang bersifat tradisional terjalin terkadang mengalami keretakan karena setiap individu masing-masing memiliki ambisi dalam meraih sebuah kedudukan dan kekuasaan tunggal yakni menjadi seorang kepala daerah. Mesti sejatinya mereka tidak ingin mengakui secara terang-terangan adanya keretakan dalam internal keluarga mereka, tetapi dalam kacamata politik tengah menghadirkan kontestasi dalam tubuh kelompok Andi ini. 


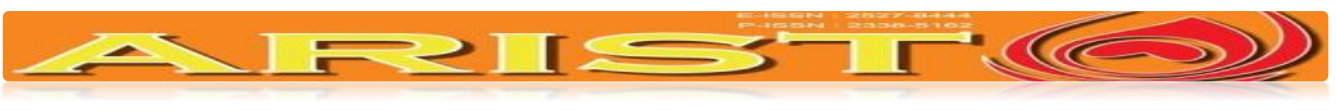

Sosial Politik Humaniora

http://journal.umpo.ac.id/index.php/aristo / aristo@umpo.ac.id

\section{Rekam Jejak Eksistensi Kaum Bangsawan}

Cerita tentang kehidupan masyarakat Bugis Makassar tertuang dalam manuskrip kuno yakni La Galigo. Dalam manuskrip tersebut pun diungkap bagaimana konsep falsafah hidup orang Bugis Makassar termasuk tata cara hidup, berperilaku hingga kepemimpinannya. Selain itu cerita tentang to manurung ${ }^{4}$ menjadi landasan bagi masyarakat umum untuk percaya akan kepemimpinan golongan ${ }^{5}$ strata atas yakni para bangsawan atau Arung dan saat ini lebih dikenal dengan masyarakat yang memiliki gelar "Andi”.

Pasca kemerdekaan Republik Indonesia yang diikuti dengan hadirnya daerah tingkat II dimana daerah tersebut merupakan bekas dari kerajaan (baik kerajaan besar maupun kerajaan kecil) yang termasuk bagian dari Negara Kesatuan Republik Indonesia.Seiring perubahan konstitusi menyangkut daerah, kemudian membutuhkan Kepala Daerah sebagai perrpanjangan tangan pemerintah pusat di daerah.Untuk itu dalam penunjukannya pemerintah pusat tentunya melirik orang kuat lokal atau orang yang paling berpengaruh di daerah masing-masing dalam mengatur wilayah dan masyarakatnya. Pada pembentukannya diawal Pinrang dipimpin oleh seorang bangsawan karena masyarakat sudah terbiasa dipimpin oleh bangsawan, kepercayaan masyarakat terhadap bangsawan ini kemudian menunjuk Andi Makkoelaoe sebagai Bupati pertama di Pinrang dengan harapan mampu mengatur masyarakat serta sistem pemerintah sesuai dengan aturan pemerintah pusat.

Eksistensi Andi di panggung politik terlihat dari dominasi mereka dalam Struktur pemerintah sejak zaman Orde Lama hingga saat ini sebagai bentuk habitus para Andi sebagai seorang pemimpin yakni sebagai kepala daerah yang terbukti rentetan Bupati yang memimpin

\footnotetext{
${ }^{4}$ Konsep To Manurung tidak berlaku didaerah Wajo, karena masyarakat disana tidak mengenal akan adanya manusia dari langit (To Manurung). To Manurung sendiri ialah gambaran tentang cara kedatangann atau kehadirannya, dankepadanya diserrahi kepercayaan buat bertindak seebagai pemimpin bagi orang banyak yang menghendakinya. Cara kehadiran yang luar biasa itu memberikan kepadanya kewibawaan yang cukup ampuh dalam melayani rakyat

${ }^{5}$ Adapun stratifikasi dalam struktur masyarakat Bugis Makassar secara umum adalah: Pertama Arungialah raja atau pemimpin di wilayahnya, dimana raja itu diangkat berdasarkan hasil keputusan masyarakat, dan atau keturunan tertentu yang berasal dari titisan dewata dan menjadi kepercayaan masyarakat sebagai kiriman dewata yang diperuntukkan menjadi pemimpin masyarakat dan mengatur segala isi jagad raya di bumi ini dalam rangka menciptakan kesejahteraan.Kedua Tau Maradeka (Orang Merdeka) yang identik dengan orang-orang yang loyal terhadap kerajaan dimana berperan sebagai pengawal dan memiliki hak untuk tinggal di kerajaan tersebut.Ketiga Ata (Hamba Sahaya) diidentikkan sebagai klien, kebanyakan orang-orang tidak ingin menggunakan istilah budak karena dianggap kata 'budak' itu tidak memiliki price dimata masyarakat dan seringkali dimarginalkan, untuk itu bagi golongan ketiga ini digunakan istilah 'ata' atau klien
} 


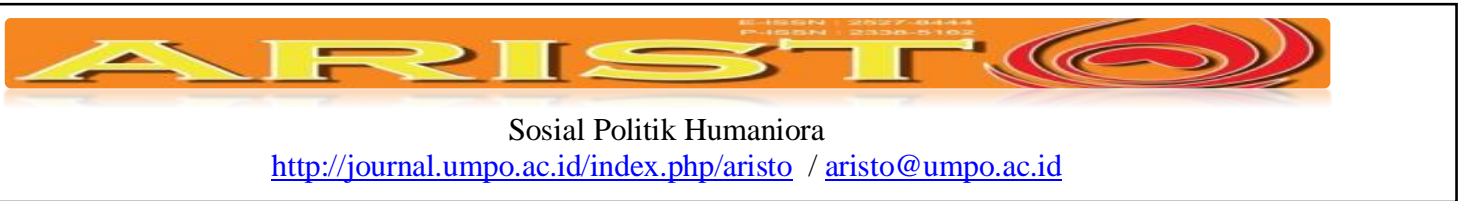

Pinrang hingga saat ini mayoritas bergelar Andi. Selain itu penerimaan masyarakat akan pola kepemimpinan dan struktur sosial tersebut tetap diterima serta terjaga hingga saat ini.

Pada fase awal sistem pemerintahan di Pinrang yang identik dengan 4 (empat) kerajaan kecil seluruhnya dipimpin oleh bangsawan. Alasan utama masyarakat memilih kaum bangsawan sebagai pemimpinnya adalah karena mereka (baca: bangsawan) identik dengan beberapa hal yakni:

1. To Manurung yakni orang yang dipercayai masyarakat bugis merupakan orang yang turun dari langit dan secara khusus diutus oleh para Dewa untuk memimpin di bumi ini. Orang yang turun dari langit inilah kemudian menikah dengan masyarakat biasa dan selanjutnya keturunan merekalah dipercayai oleh masyarakat bugis mengangkat mereka sebagai pemimpin;

2. To Warani yakni orang yang berani melindungi masyarakatnya dari gangguan luar;

3. To Acca' yakni orang yang pintar karena dulunya hanya kaum bangsawan yang memiliki kesempatan untuk menuntut ilmu/sekolah karena memiliki modal ekonomi yang banyak, seperti menjadi tuan tanah dan sebagai pengusaha sukses;

4. To Sugi' yang berarti orang kaya, dimana dengan kekayaan mereka mampu menciptakan kesejahteraan bagi masyarakatnya.

Berdasarkan karakter inilah yang dimiliki oleh para bangsawan inilah yang menjadikan mereka memiliki banyak pengikut/basis massa. Selain itu kepercayaan penuh dari masyarakat biasa untuk meminta perlindungan kepada bangsawan merupakan modal utama mereka dalam memerintah atau menjadi pemimpin. Konsep to sugi yang melekat pada bangsawan dikarenakan mereka memiliki harta benda serta menguasai sumber-sumber produktivitas perekonomian seperti menjadi tuan tanah. Meski menjadi tuan tanah serta menguasai bidang perekonomian lainnya, tidak serta merta menjadikan para bangsawan di Sulawesi Selatan ini semena-mena terhadap kliennya. Hadirnya konsep sipakatau, sipakainge dan sipakalebbi ${ }^{6}$ di Sulawesi Selatan

\footnotetext{
${ }^{6}$ Sipakatau terkait dengan bagaimana individu menghargai satu sama lain, ataupun dikenal dengan istilah memanusiakan manusia. Dimana kita dituntut untuk saling menghargai hak dan kewajiban satu sama lain. Antara sang penguasa dan yang dikuasai diharapkan adanya sikap saling menghargai dan menyokong satu sama lain, karena tidak dapat dipungkiri bahwa sang penguasa tentunya membutuhkan dukungan dari masyarakat bawah dalam memenuhi kepentingannya, serta masyarakat bawah pun membutuhkan pemimpin yang mampu memberikan kesejahteraan bagi mereka.

Sipakalebbi' identik dengan puji-pujian. Yang berarti sesama manusia senantiasa saling memuji satu sama lain dan saling menghargai demi menjaga keharmonisan kehidupan sehari-hari. Manusia biasa tidak dapat
} 


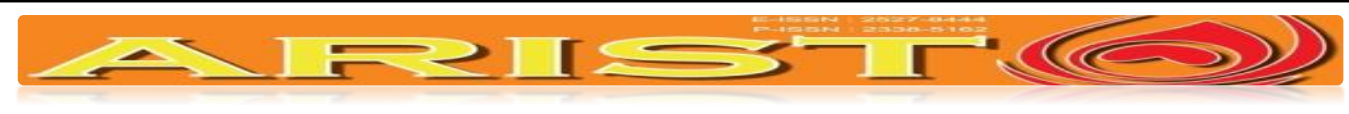

Sosial Politik Humaniora

http://journal.umpo.ac.id/index.php/aristo / aristo@umpo.ac.id

menjadi penyeimbang dalam struktur sosial masyarakat Bugis dan Makassar agar para elit yang menjadi tuan tanah (patron) menjaga kliennya. Hal ini mengingat habitus itu menentukan tingkat keberhasilan serta kegagalan agen dalam mempertahankan posisinya serta mengakumulasi sumber daya yang dimiliki.Dibutuhkan adanya kreatifitas para agen dalam memproduksi kekuasaan di arena tertentu yang diinginkannya.

Kriteria kepemimpinan yang diharapkan oleh masyarakat diyakini terdapat pada sosok keturunan bangsawan, untuk itu dalam struktur pemerintahan mulai dari zaman Hindia Belanda tidak terlepas dari tangan keturunan bangsawan ini. Selain itu Belanda senantiasa menjalin kerja sama dengan bangsawan tersebut karena sebagai elit lokal mereka tentunya mendapatkan tempat dalam struktur sosialnya atau memiliki basis massa yang tetap.

Pada masa pemerintahan Hindia Belanda antara 1906-1942 membentuk susunan pemerintahan di Sulawesi dan daerah bawahannya (Gouvernment Celebesen Ondehoorigheden) yang memiliki aturan tingkatan hingga ke bawah bagian pemerintahan (afdeling), cabang pemerintahan (onderafdeling), daerah adat (adatgemeenschap) dan kampong (kampong). Semua tingkatan pemerintahan tersebut berada di bawah pimpinan pejabat pemerintahan Belanda yang masing-masing diurut mulai dari pejabat asisten (assistant resident) dan kontrolir (controleur), tingkat cabang pemerintahan dan daerah adat dijabat oleh regen (regent), dan kepala kampung (hoofd) (Poelinggomang, 2004: 3-4). Adapaun pejabat daerah adat dipegang oleh bangsawan lokal hal ini berdasarkan aturan dan kebiasaan para masyarakat yang memnunjuk langsung pemimpinnya berdasarkan hasil kesepakatan bersama.Adapun bangsawan yang ditunjuk merupakan bangsawan yang memiliki darah murni atau memiliki kedudukan yang lebih tinggi dibandingkan bangsawan lainnya.Kemudian bangsawan yang ditunjuk itu berdasarkan

dipisahkan dengan hati nurani, yang senantiasa menyenangi segala hal yang berbau dengan keindahan baik berupa barang hingga kata-kata atau pujian. Mengakui kelebihan orang lain serta kekurangan diri sendiri, dan menerima semua keadaan itu dengan hati yang terbuka serta saling menutupi kekurangan masing-masing atau saling bahu membahu dalam segala kegiatan merupakan bentuk perngharagaan terhadap satu sama lain.

Sipakainge' ini diperlukan dalam kehidupan kita karena bertujuan untuk saling mengingatkan, memberikan masukan baik berupa kritik dan saran satu sama lain. Mengingat kita sebagai manusia biasa tidak terlepas dari kekhilafan dan dosa sehingga sebagai manusia yang hidup dalam struktur masyarakat diharapakan saling mengingatkan ketika kita melakukan tindakan yang diluar norma dan etika yang ada. Kritik dan saran ini tentunya dibutuhkan untuk melakukan perbaikan atas kesalahan dan kekurangan yang dilakukan. Misalnya saja para pemimpin yang telah melakukan kesalahan, maka masyarakat berkewajiban untuk mengingatkan pemimpin mereka bahwa pemimpin ini bersikap diluar norma dan etika. Dan sebagai pemimpin pun harus lapang dada untuk menerima kritikan dan saran dari masyarakat. 


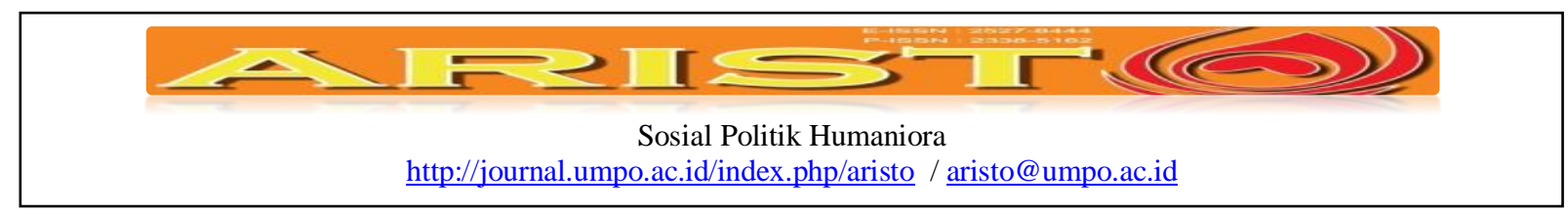

persetujuan dari pemerintah Hindia Belanda.Untuk itu para bangsawan lokal yang notabene sebagai local strongman kemudian menjalin hubungan kerjasama dalam mempertahankan kekuasaan serta memperoleh jabatan strategis dalam struktur pemerintahan.

Namun tidak semua sistem pemerintahan bentukan Belanda diterima oleh bangsawan ${ }^{7}$ dan masyarakat menerimanya, maka dari itu terjadi gerakan-gerakan separatis mulai dari aksi perampokan dari pemberontakan yang dipimpin langsung oleh bangsawan lokal dalam menentang peraturan pemerintahan Hindia Belanda.Gerakan-geraka separatis tersebut berpatokan pada kehendak para bangsawan yang tidak ingin kebesaran dan kekuasaan mereka hilang serta didominasi oleh pemerintah Belanda.Selain itu masyarakat sendiri tidak menginginkan adanya perubahan kondisi politik tradisional yang telah menjadi struktur kehidupan perpolitikan mereka. Dimana sang pemimpin dipilih dan diangkat berdasarkan hasil kesepakatan bersama, dimana bangsawan yang memenuhi kriteria tertentu yang dapat dipilih menjadi pemimpin. Kriteria bangsawan sepertiTo acca, To warani dan To sugi yang disinyalir dapat menciptakan kesejahteraan bagi masyarakat. Pasca kemerdekaan Republik Indonesia semua daerah yang menjadi bagian dari Negara Kesatuan Republik Indonesia menyerahkan segala kebebasannya termasuk sistem pemerintahannya kepada pusat ${ }^{8}$.Meski demikian para pemimpin pusat yakni presiden tetap memperhatikan orang-orang yang memiliki pengaruh di daerah masing-masing termasuk bangsawan lokal.

Setiap swapraja yang dulunya terdiri dari kerajaan kecil secara adminsitrasi pemerintahan diduduki oleh golongan bangsawan. Tidak hanya menjadi pegawai pemerintahan bangsawan lainnya juga terjun dalam dunia usaha atau di bidang ekonomi, serta menjadi tuan tanah dan melanjutkan pendidikan mereka sebagai persiapan untuk terjun di dunia birokrasi dan pemerintahan daerah. Dengan pendidikan yang lebih tinggi serta gelar Andi yang disandangnya dianggap memudahkan mereka untuk mendapatkan jabatan strategis dalam birokrasi.Hal inilah yang membuat golongan non bangsawan terasa tersingkirkan ketika berkompetisi memperebutkan kedudukan. Untuk itu golongan non bangsawan beralih strategis dengan

\footnotetext{
${ }^{7}$ Bangsawan yang dimaksud dari berbagai kerajaan yang ada di Sulawesi Selatan baik tiga kerajaan besar yakni Luwu, Bone dan Gowa serta kerajaan-kerajaan kecil lainnya yang tentunya memiliki sistem administrasi pemerintahan sendiri.

${ }^{8}$ Kecuali Daerah Istimewa Yogyakarta, meskipun menyerahkan sistem pemerintahan diatur dan dibentuk berdasarkan peraturan pemerintahan pusat tetapi tidak secara penuh, dimana kepala daerahnya tetap dipimpin oleh sang raja atau sultan dan tidak melalui proses pemilihan kepala daerah.
} 


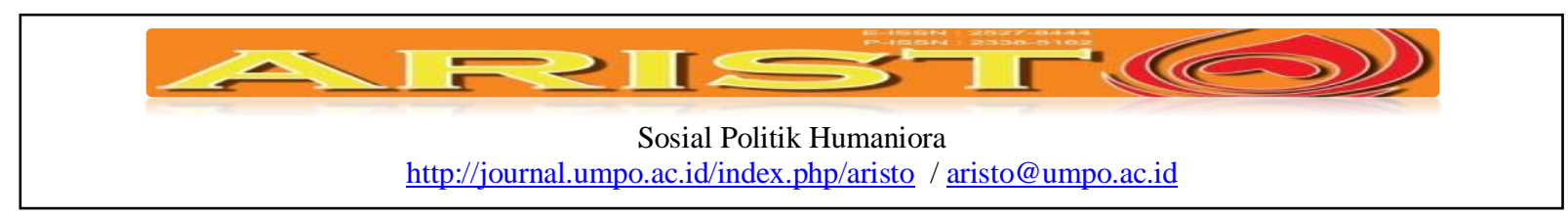

menguasai bidang perekonomian dengan menjadi pedagang serta terus melanjutkan pendidikannya, selain itu strategi lain untuk mendongkrak status sosial mereka (Baca: Golongan non bangsawan) yakni menikahkan anak atau puteri mereka dengan orang yang berstatus bangsawan. Secara otomotasi keturunan mereka pun akan mendapatkan gelar Andi dari hasil perkawinan dengan kaum bangsawan. Tetapi bukan hanya golongan biasa yang hendak meningkatkan derajat sosial dan ekonomi mereka, golongan bangsawan pun tetap berusaha menjaga kekentalan darah kebangsawanan mereka dengan menikahkan anak mereka dengan sesama Andi.Sebab meningkatnya rakyat biasa yang semakin sukses merupakan ancaman bagi golongan bangsawan ini yang semakin sedikit.

Salah satu kasus dimana rakyat dari golongan non bangsawan yang terkenal pemuda pemberani dari Luwu bernama Kahar Muzakkar (1949-1958) menciptakan gerakan separatis dan anti aistokrasi. Kahar Muzakkar merupakan hasil didikan dari sekolah islam dan menganut paham egaliter dan anti aristokrasi melakukan gerakar secara gerilya di hutan Sulawesi Selatan dengan dukungan rakyat biasa dan sebagian bangsawan biasa. Namun pemberontakan yang dilakukan oleh Kahar gagal karena tidak memiliki strategis administrates yang cocok untuk diterapkan yang sesuai dengan nilai budaya dan ideologi yang dianut oleh para pendukungnya. Pada akhirnya para pemberontak menerima kebijakan pembentukan pemerintahan yang diatur oleh pemerintah pusat di Jakarta.

Berbeda dengan bangsawan pofesional lainnya yang justru mengikuti alur pemerintahan pasca kemerdekaan dan terbentuk Negara Kesatuan Republik Indonesia. Seperti yang dilakukan oleh bangsawan bugis yakni Jusuf ${ }^{9}$ menganggap bahwa masa memanfaatkan gelar "kebangsawanan" telah habis, untuk merebut kontrol atas wilayah, mereka harus bergabung dengan ihak yang saat ini memegang tampuk pemerintahan, bukannya menentang mereka ( Susan Bolyard Millar, 2009:71). Selain itu para bangsawan semakin memperkuat jaringan mereka dengan pemerintah pusat dengan cara bergabung dalam militer dan birokrasi pemerintahan.

Konteks Pinrang sendiri yang mulai pasca kemerdekaan Kepala Daerah dipimpin oleh bangsawan yakni Andi Makkoelaoe, meskipun pada awal kemerdekaan para Bupati ditunjuk langsung oleh pemerintah pusat. Beliau merupakan keturunan dari raja Kerjaan Sawitto, sebagai

\footnotetext{
${ }^{9}$ Bangsawan dari Bone ini telah melepaskan gelar kebangsawanannya 'Andi'.
} 


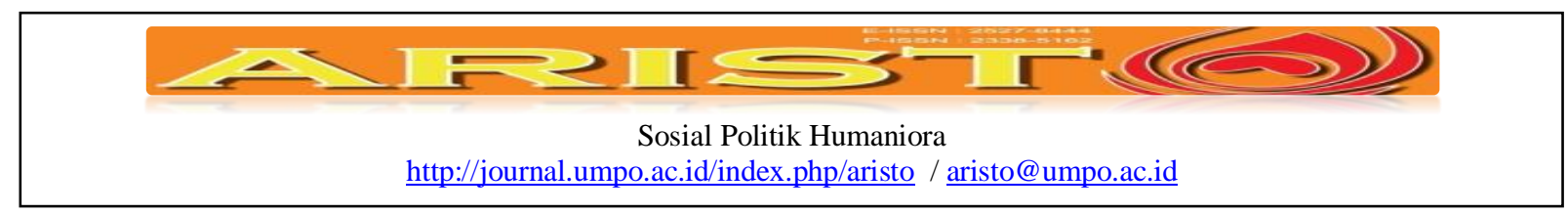

bangsawan yang memiliki pengaruh terhadap rakyatnya memudahkannya untuk menduduki jabatan kepala daerah.Selanjutnya bupati Pinrang tetap dipegang oleh golongan bangsawan, adapun golongan rakyat biasa hanya yang memiliki pendidikan tinggi saja yang mendapatkan jabatan strategis dalam birokrasi.

Hal ini kemudian mendorong para Andi dan rakyat biasa berlomba-lomba untuk melanjutkan pendidikannya ataupun tergabung dalam militer untuk sebagai strategi untuk dekat dengan kekuasaan, selain itu para Andi juga berupaya untuk menguasai bidang perekonomian dengan menjadi tuan tanah atau menjadi pengusaha. Meski tidak mudah menggeser posisi Andi di mata masyarakat untuk menjadi pemimpin karena adanya doktrinisasi dalam proses pemilihan pemimpin, masyarakat pun dihadapkan dengan berbagai kapital yang dimiliki oleh para Andi sedemikian kompleks membentuk kekuatan besar bagi mereka untuk tetap survive.

\section{Peta Pertarungan Kaum Bangsawan di Arena Pilkada}

Pertarungan untuk mendapatkan kekuasaan telah terjadi di masa lalu dimana para elit lokal berperang untuk menduduki suatu wilayah yang dikehendakinya. Penaklukan wilayah pun tidak serta merta hanya dilakukan melalui pertumpahan darah, adanya diplomasi antara kerajaan satu dengan yang lain untuk menjalin kerja sama demi menciptakan kesejateraan rakyat serta memperluas pengaruhnya sebagai pemimpin. Dalam konteks kekinian relasi yang terbangun menjadi salah satu modal yang dimanfaatkan oleh elit lokal untuk berkontestasi di panggung politik termasuk pilkada.Egoisme untuk menjadi pemimpin sejatinya justru merusak tatanan sistem kekerabatan yang terjalin, termasuk yang terjadi pada para Andi di Pinrang, pada pertarungan politik lokal yang terjadi justru melahirkan ketidaksolidan di mata masyarakat.

Sebagai identitas kultur yang melekat pada diri para Andi sekiranya dapat membentuk komunitas yang solid. Namun kesolidan itu tidak dapat terwujud ketika dihadapkan dengan kekuasaan yang melibatkan kepentingan pribadi.Pilkada secara langsung sebagai arena politik untuk memperoleh kekuasaan tunggal layaknya sebuah adegan pertarungan yang dipertontonkan oleh para Andi di arena politik yang menyajikan segala sumber daya yang mereka miliki untuk mendapatkan dukungan masyarakat.

Pilkada tahun 2009 sebagai langkah awal masyarakat Pinrang untuk menentukan secara langsung sang pemimpin. Euforia demokrasi dalam proses pemilihan kepala daerah hal baru 


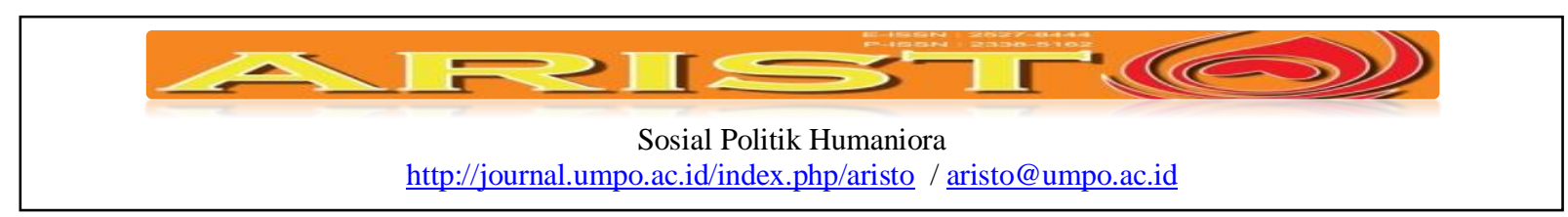

yang dirasakan bukan hanya bagi masyarakat sebagai sang pemilih atau penentu namun para kandidat yang mencalonkan diri sebagai Bupati Pinrang pun menerima hal itu sebagai dampak liberalisasi politik. Semua orang memiliki hak yang sama untuk menjadi sang pemimpin. Kesempatan ini dimanfaatkan oleh para Andi agar tetap survive dalam politik.

Namun para Andi ini memiliki kepentingan individu, bukannya saling mendukung satu sama lain justru berbalik saling serang. Hal inilah yang terjadi dalam lingkup internal keluarga Andi Aslam Patonangi dan Andi Irwan Hamid.Sebagai satu rumpun keluarga justru menjadi lawan politik dalam pertarungan pilkada di Pinrang. Mulai pada pilkada tahun 2009 satu rumpun keluarga ini bertarung dalam arena tersebut (Baca: Pilkada).

Sebelum pilkada 2009 para tokoh masyarakat dan tomatoa dalam lingkup keluarga para Andi melakukan konsolidasi di Suppa bertempat di rumah Petta Wanreng (almarhum) dalam menentukan siapa yang diusung dari keluarga mereka untuk mencalonkan diri sebagai Bupati pada tahun 2009. Kemunculan Andi Aslam Patonangi yang berpasangan dengan Andi Kaharuddin Machmud tentunya menjadi rival politik Andi Irwan Hamid pada Pilakada $2009^{10}$, hal ini menunjukkan adanya keretakan dalam internal keluarga Andi ini meski telah dilakukan konsolidasi sebagai upaya penyatuan suara. Namun adanya kepentingan pribadi sehingga Andi Aslam bersama Andi Kaharuddin kemudian berkontestasi dalam arena politik. Untuk itu menurut Kak Accha bahwa "dalam dunia politik yang namanya hubungan persaudaraan akan habis, jangankan teman, saudara pun ditinggalkan ketika kepentingan berbeda”.

Konstestasi sengit yang terjadi pada pilkada 2009 dimana tidak adanya sang incumbent yang tampil serta yang bertarung merupakan satu rumpun keluarga bangsawan. Terjadinya putaran kedua yang mana Andi Aslam Patonangi berpasangan dengan Andi Kaharuddin Machmud vz andi Irwan Hamid dengan Andi Rahmi pada waktu sangat sengit dimana kedua pasangan ini sama-sama memiliki capital yang hampir setara. Namun yang berhasil memenangkan pilkada tahun 2009 adalah pasangan Andi Aslam Patonangi dengan Andi Kaharuddin (ASKAR) dimana Andi Aslam sebagai anak dari salah satu mantan Bupati Pinrang

\footnotetext{
${ }^{10}$ Adapun nama-nama calon kandidat Bupati Pinrang pada pilkada 2009 antara lain adalah: Ali Usman dan ahmad Paturusi dari PDK (Diusung oleh Partai Demokrasi Kebangsaan), Andi Irwan dan A. Rahmi (Diusung oleh Golkar), Kadir Faiz dan Amir Manggopo (Diusung oleh PKS), Syamsuddin Manja' dan Andi Renreng (Independent), La Kama Wiyaka dan H. Sulaiman (Independent), Andi Aslam Patonangi dan Andi Kaharuddin (Diusung oleh PPP dan PDI-P)
} 


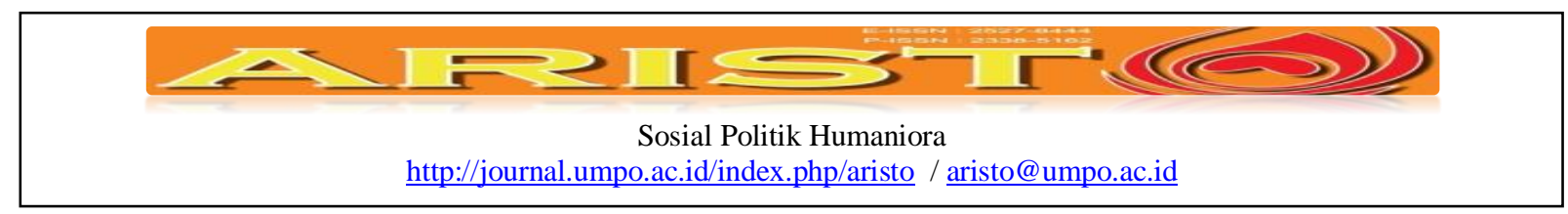

yakni Andi Patonangi diharapkan oleh masyarakat Pinrang dapat menahkodai wilayah yang dikuasai menjadi lebih baik, karena secara genetis Andi Aslam merupakan keturunan seorang pemimpin lokal ${ }^{11}$.

Terjadinya keretakan internal keluarga Andi pada pilkada 2009 kemudian terulang kembali pada pilkada 2013, pertarungan semakin sengit karena terjadi disharmonisasi antara Andi Aslam dengan Andi Kaharuddin yang berpasangan pada periode pertama kini Andi Kaharuddin justru mencalonkan diri sebagai Bupati Pinrang periode 2014-2015. Sehingga bukan hanya pertarungan antara non bangsawan melawan bangsawan ${ }^{12}$ tetapi kontestasi sesama bangsawan yang notabene masih satu keluarga.

Kepemilikan capital para Andi serta pemanfaatan modal tersebut kemudian dikontsruksikan sebagai upaya dalam meraih kesuksesan di pilkada.Mulai dari capital kultural yang seringkali menjadi wacana pada saat kampanye dimana sebagai dasar untuk menjadi seorang pemimpin yang berkualitas, selain itu kepribadian yang bersahaja dan merakyat senantiasa ditunjukkan dalam menarik simpatisan masyarakat. Para Andi ini masing-masing mengklaim dirinya yang pantas untuk menduduki jabatan Bupati seperti ungkapan Andi Kaharuddin "dirinya memiliki kapasitas dan kapabilitas dalam menahkodai Pinrang 5 tahun kedepannya, karena berbicara pengalaman beliau dalam dunia birokrasi selama \pm 10 tahun" (Wawancara Andi Kaharuddin pada tanggal 10 September 2013 di Rumah Jabatan Wakil Bupati Pinrang). Selain itu menurut analisa salah satu tim sukses beliau atas kemampuannya yakni "Modal yang dimiliki secara personality luar biasa karena awal karier beliau (Baca: Andi Kaharuddin) dimulai dengan Kepala Desa, kemudian pernah menjabat sebagai camat, sebagai

\footnotetext{
${ }^{11}$ Pada masa kepemimpinan Andi Nawir sistem pemerintahan di Pinrang identik dengan aristokrasi dimana hanya bangsawan serta orang-orang terdekatnya saja yang diberikan jabatan.Selain itu korupsi yang bersifat latentmenjadikan masyarakat mencari sosok pemimpin baru yang bukan berasal dari kroni-kroni Andi Nawir.Pasangan Andi Aslam dengan Andi Kaharuddin disinyalir sebagai pasangan yang netral dan tidak memiliki hubungan dari pemimpin sebelumnya.Berbeda dengan Andi Irwan Hamid yang mana pada saat Andi Nawir mencalonkan diri sebagai bupati periode pertama dan kedua merupakan pendukung setia beliau.Untuk itu ketika Andi Irwan sendiri maju mencalonkan sebagai Bupati pada tahun 2009, dikhawatirkan praktik sistem aristokrasi tetap diberlakukan. Selain itu secara genealogis Andi Irwan berasal dari keluarga pengusaha, yang berbeda dengan Andi Aslam secara genetic merupakan keturunan sang pemimpin. (Wawancara dengan Arsyad pada tanggal 23 November 2013)

${ }^{12}$ Dimana $50 \%$ kalangan non bangsawan serta $50 \%$ kalangan bangsawan.Pencalonan di kalangan non bangsawan sebagai suatu upaya mengubah habitus mereka dari orang biasa untuk menjadi seorang pemimpin.Selain itu pencalonan inipun sebagai gerakan para masyarakat golongan biasa dalam meningkatkan status sosial mereka yang hendak setara dengan para bangsawan yang mana habitusnya senantiasa mendominasi jabatan dalam pemerintah serta menjadi seorang pemimpin.
} 


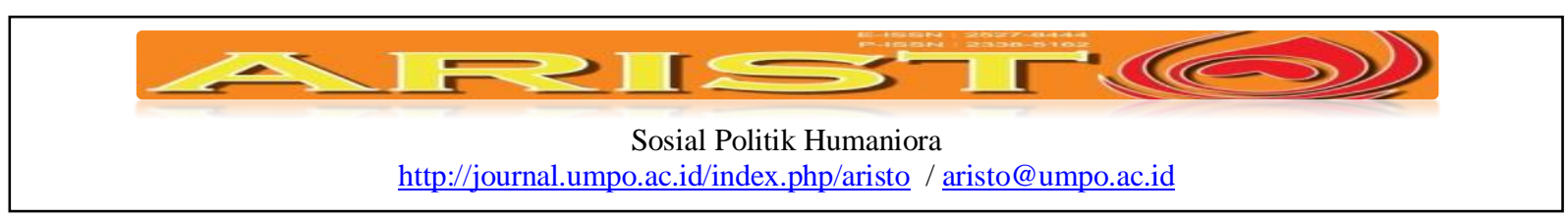

pamong yang senior, serta jabatan-jabatan strategis menjadi modal terbesar untuk menata pemerintahan yang lebih baik karena telah memiliki pengalaman pemerintahan untuk memimpin" (wawancara dengan Pak Musli pada tanggal 30 Agustus 2013 di Posko Induk Tim Kerja untuk AKBAR).

Dengan kepercayaan diri serta modal yang dimiliki oleh Andi Kaharuddin kemudian memutuskan untuk tidak mendampingi Andi Aslam dalam pilkada tahun 2013. Selain itu alasan utama beliau yang termaktub dalam visi dan misinya serta senantiasa dilontarkan pada saat debat kandidat adalah "Beliau gerah dengan praktik korupsi secara latent didepan matanya". Hal ini kemudian menjadi sorotan panelis yakni Dr Jayadi Nas M.Si ${ }^{13}$ dengan pernyataan Andi Kaharuddin tersebut, karena sebagai Wakil Bupati Pinrang periode 2009-2014 tentunya memiliki tanggung jawab dan wewenang dalam masalah pengawasan praktik korupsi yang terjadi.

Jadi menurut beliau ketika praktik korupsi terjadi didepan mata sang wakil Bupati menjadi tanggung jawabnya untuk menindaklanjuti kasus tersebut, hal inilah yang menjadi pertanyaan menjebak Andi Kaharuddin pada saat debat kandidat. Saling serang tidak hanya terjadi dalam debat kandidat yang dilaksanakan pada tanggal 14 September 2013 bertempat di Gedung Olahraga Andi Makkoelaoe, tetapi black campaign berupa selebaran sebagai pembunuhan karakter pun menjadi wacana yang beredar di masyarakat sebagai senjata para kandidat lainnya.

\section{Dominasi Simbolik dalam Proses Pertarungan di Arena Pilkada}

Pasca dilaksanakannya pilkada pada 18 September 2013 yang menetapkan pasangan Andi Aslam Patonangi dengan Darwis Bastama sebagai Bupati dan Wakil Bupati terpilih periode 2014-2019 sebagai bentuk kepercayaan sebagian masyarakat Pinrang untuk memberi kesempatan yang kedua bagi Andi Aslam untuk membangun Pinrang lebih baik lagi. Berdasarkan perolehan suara yang dimenangkan oleh pasangan Andi Aslam Patonangi - Darsiw Bastama (A2P Berdarma) kemudian disusul oleh Andi Irwan Hamid Hamid - Andi Mappanyukki (IDAMAN) sebagai bentuk keberhasilan para Andi dalam mengkontruksi dan memanfaatkan modal yang mereka miliki. Berbeda dengan pasangan Andi Kaharuddin Machmud - Ardan AP (AKBAR) yang berada pada urutan keempat setelah pasangan Abdullah

\footnotetext{
${ }^{13}$ Dr Jayadi Nas M.Si merupakan mantan ketua KPU Provinsi Sulawesi Selatan dan salah satu dosen program Studi Ilmu Pemerintahan Jurusan Politik dan Pemerintahan di Universitas Hasanuddin.
} 


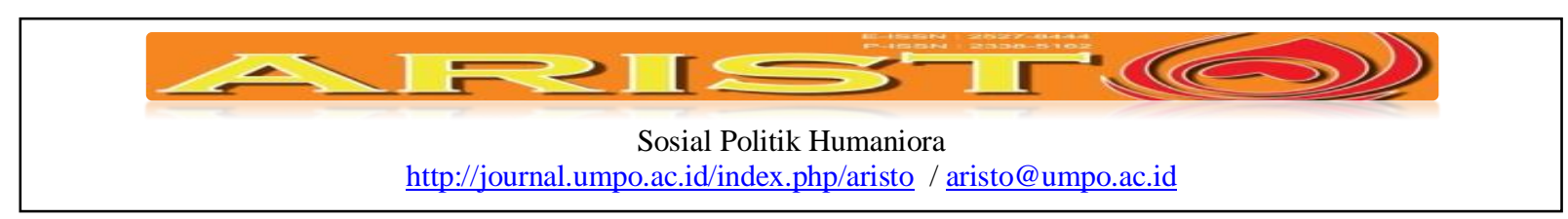

Rasyid dengan Faisal Tahir Syarkawi (Idola Fathir), justru dikalahkan oleh pengusaha dan bentuk kegagalan sang aktor dalam memaksimalkan modal simbolik yang dimilikinya.

Meski ketiga kandidat ini yang berlatar belakang bangsawan dan merupakan satu rumpun keluarga, tetapi dalam pemanfaatan modal-modal yang mereka miliki tentunya menjadi penentu tingkat keberhasilan mereka dalam mendapatkan suara masyarakat.Modal simbolik yang masingmasing dimiliki kandidat hanyalah memberikan nilai tambahan lebih di mata masyarakat, nilai tambahan itupun berlaku pada golongan atau kelompok masyarakat yang mengetahui kepemimpinan secara genetis.Dimana para pemimpin tentunya lahir dari darah seorang pemimpin ataupun pejuang juga, historis ini kemudian menciptakan genealogis kekuasaan yang hidup dalam pikiran masyarakat bahwa keturunan pemimpin tetap eksis dan memiliki karisma tersendiri secara lahiriah untuk menjadi seorang pemimpin. Tidak cukup hanya menggunakan gelar simbolik sebagai strategis untuk mendominasi masyarakat dalam mendapatkan dukungan dalam arena politik, apalagi saat dihadapkan rival politik yang memiliki modal yang sama untuk itu dibutuhkan hadirnya modal-modal lain.

Modal yang sangat dibutuhkan untuk menjadi seorang pemimpin adalah modal sosial dimana jaringan yang dimiliki serigkali dikonstruksikan para kandidat ataupun elit politik menjadi modal ekonomi untuk membantu mereka dalam hal pembiayaan setiap proses kampanye dan mobilisasi massa. Adapun status pendidikan yang diraih oleh para kandidat itu sendiri merupakan nilai tambahan bagi masyarakat bahwa kandida yang dipilih adalah orang yang tepat karena memiliki tingkat pengetahuan yang cukup dalam mengambil suatu kebijakan.

Kemenangan yang diperoleh pasangan Andi Aslam Patonangi dengan Darwis Bastama di arena pilkada Pinrang tidak terlepas dari pemanfaatan modal sosial yang dimiliki kedua kandidat ini. Seperti pengakuan Andi Aslam pada saat diwawancari di rumah jabatan Bupati Pinrang di jalan A. Pawelloi pada tanggal 2 Oktober 2013 yang menyatakan bahwa pada pilkada kemarin beliau cenderung memanfaatkan para relasi ataupun jaringannya mulai dari PNS, pengusaha hingga wiraswasta. Selain itu beliau pun berharap agar masyarakat jeli dan melihat secara objektif semua perubahan-perubahan yang terjadi di Pinrang serta kinerja kerja pemerintahan waktu periode pertama kepemimpinannya. Pemanfaatan jaringan tersebut merupakan strategi beliau dalam memobolisasi massa dimana hubungan antar masyarakat sebagai pondasi awal yang dibangunnya selama ini. 


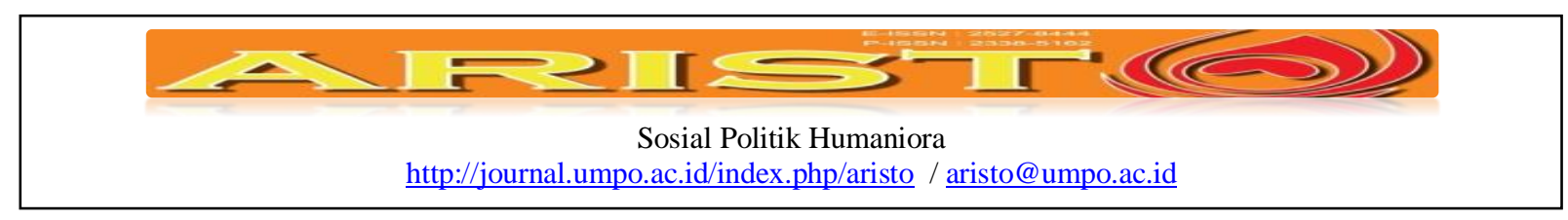

Dari segi capital yang dimiliki oleh sang incumbent berupa modal sosial yang dibangunnya sejak menjabat sebagai birokrat hingga menjadi Bupati Pinrang periode 2009-2014 memiliki dominasi serta hegemoni di kalangan PNS (Pegawai Negeri Sipil serta pejabat pemerintahan dalam menentukan pilihan dalam pilkada tahun 2013. Dominasi tersebut berupa mutasi ataupun turun tahta/jabatan bagi PNS yang ketahuan tidak mendukung sang incumbent. Selain itu dalam proses mobilisasi massa terdapat 2 (dua) macam pemilih yakni strong voter dan swing voter. Strong voter ini merupakan basis massa yang kuat serta setia terhadap sang kandidat, dalam hal ini beliau sangat yakin masih memiliki strong voter yang menghargai penghargaan-penghargaan serta pencapaian yang dibangun beliau selama menjabat sebagai Bupati 1 periode. Sebagai strong voter ini merupakan massa yang tidak dapat goyah atau berpindah pilihan meski disuap oleh kandidat lainnya. Berbeda dengan swing voter yang tidak memiliki prinsip dan kejelasan pilihan, yang sangat mudah berpindah ke lain kandidat ketika disuap atau dihadapkan dengan money politic. Money politic inilah seringkali mengecohkan pilihan sang pemilih ketika termasuk kategori swing voter yang tidak memiliki ikatan yang sangat kuat terhadap satu kandidat.

Meski tidak memberikan kontribusi yang besar gelar ini tetap memiliki pengaruh terhadap tokoh masyarakat atau orang tua yang memiliki kedekatan oleh bangsawan dulu. Selain itu para elit saat ini yang mengetahui bahwa bangsawan memiliki karakter pemimpinnya yang menjadi habitus mereka tentunya memilih salah satu dari ketiga Andi yang berkontestasi. Meski memiliki gelar yang sama namun habitus dari ketiganya memiliki perbedaan, hal inilah yang menjadi pertimbangan bagi masyarakat terutama para tokoh masyarakat untuk menjatuhkan pilihan. Dominasi simbolik yang di back up oleh multi sosial menciptakan kontestasi yang terpolarisasi, dimana semua “Andi" merasa berhak untuk menjadi seorang pemimpin baik yang muda ataupun tua.Hal ini terlihat dari ketiga Andi ini yang memenangkan pertarungan tersebut justru yang lebih muda diantara ketiganya. Merasa memiliki basis massa yang kuat menjadikan pilkada ini sebagai panggung yang memicu para Andi untuk memaksimalkan modal yang dimiliki. 


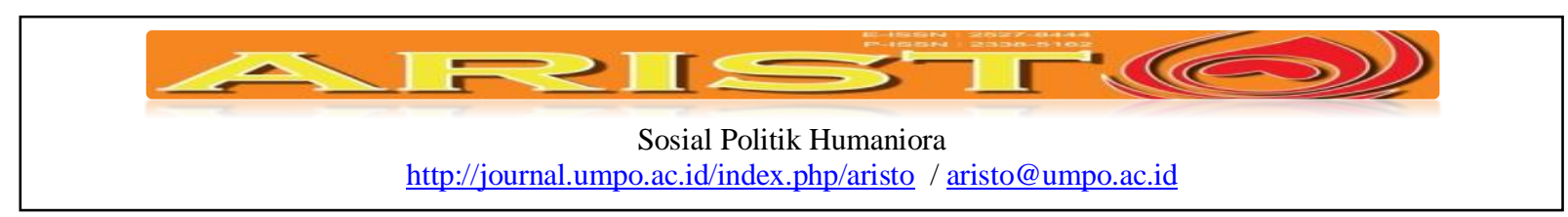

\section{Kesimpulan}

Dalam arena politik, fenomena kontestasi para elit utamanya kaum bangsawan akan semakin menarik ketika status dikatikan dengan praktik yang dilakukan oleh individu hingga kelompok masyarakat dalam menyusun peta kekuatannya. Selain status yang menjadi faktor penentu para elit dalam memainkan perannya di arena politik, tidak dapat diabaikan pula adanya habitus para aktor tersebut. Konsep habitus dari Pierre Bourdieu sangat dibutuhkan dalam melihat kontruksi perilaku para bangsawan baik sebagai individu maupun kelompok yang bersinggungan dengan arena kekuasaan. Dimana pada masa Orde Baru meski bersifat sentralistik yakni sang kepala daerah ditunjuk langsung oleh pemerintah pusat tidak membuat bangsawan kehilangan powerserta kharismanya di masyarakat dan era kini mereka menemukan momentum.Pada masa reformasi yang identik dengan liberalisasi politik dimana setiap masyarkat memiliki kesempatan yang sama dalam menunjukkan apresiasinya dalam panggung politik mulai lokal hingga nasional. Penggunaan konsep oleh Bourdieu disadari sangat membantu dalam menganalisa fenomena praktik politik lokal yang terjadi di lokasi penelitian.Namun dalam penggunaan teorisasi yang disajikan oleh Bourdieu tentunya terdapat kekurangan yang ditemukan berdasarkan esensi penelitian ini. 1). Bangunan kontruksi habitus Andi serta masyarakat dalam struktur sosial di pinrang saling terkait dan dibangkitkan kembali dalam proses kontestasi di arena pilkada.Adanya praktik liberaliasasi politik yang menampilkan kembali para aktor lokal yakni para bangsawan ini justru berimplikasi pada keretakan di tubuh bangsawan itu sendiri dan berujung pada konflik yang terjadi di arena pilkada. Hal ini didasari pada perubahan makna dari gelar "Andi” itu sendiri yang dianggap hanya menempel pada nama seseorang saja, ketika tidak dihadirkan oleh habitus yang mampu diterima oleh masyarakat sekelilingnya akan cenderung mendapat penolakan dari masyarakat tersebut. adapun yang menjadi struktur masyarakat itu tetap mempertahankan konsep kepemimpinan bangsawan. Habitus itu pula dapat dipandang oleh struktur yang ada untuk menentukan kapabilitas serta kapasitas seseorang dalam bertarung di arena kuasa.Tidak dapat dihindari bahwa habitus tetap memiliki pengaruh terhadap pilihan masyarakat. 2). Selain habitus yang membentuk pola pikir masyarakat dalam menentukan karakter kepemimpinan tidak dipungkiri hadinya modal sebagai pendukung aktor untuk menjadi pemimpin pun dibutuhkan.Modal-modal yang dibutuhkan seperti modal simbolik, ekonomi, sosial dan kultural inilah yang kemudian diaplikasikan dalam 


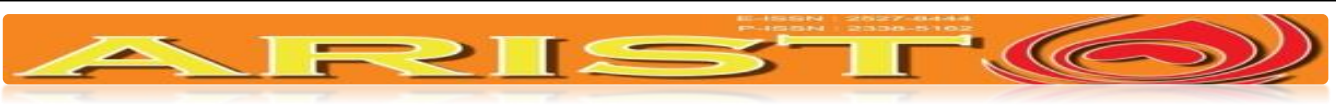

Sosial Politik Humaniora

http://journal.umpo.ac.id/index.php/aristo / aristo@umpo.ac.id

kehidupan dalam mendapatkan dukungan masyarakat. Dalam proses kontestasi Andi di arena pilkada Nampak jelas adanya praktik dominasi simbolik yang dikemukakan oleh Bourdieo identik dengan "siapa yang mendominasi dan didominasi" secara terbuka dan begitu saja diterima oleh yang didominasi. Hal ini karena yang mendominasi memiliki kuasa dalam mendominasi sang 'korban' sedangkan sang korban menerimanya begitu saja. Seperti yang terjadi pada dominasi laki-laki terhadap wanita dalam rumah tangga, laki-laki yang dianggap sebagai kepala rumah tangga memiliki kuasa terhadap istrinya yang dianggapnya sebagai subordinasi tersebut. 3). Adanya habitus dan modal tersebut kemudian diaktualisasikan dalam suatu arena yakni pilkada.Konsep arena yang dimaksudkan oleh Borudieu sebagai wadah bertarungnya segala kekuatan dan modal, didalamnya terdapat aturan main untuk para aktor. Andi sebagai gelar yang didapatkan berdasarkan garis keturunan terkadang menjadi arena itu sendiri tatkala masyarakat dari kalangan biasa melakukan pembelian 'darah' untuk mendapatkan gelar tersebut melalui proses menaikkan derajat mereka. Mulai dari tampil sebagai aktor baru yang menguasai kapital ekonomi, memiliki gelar pendidikan setinggi-tingginya serta membangun jaringan sosialnya. Proses transformasi dari masyarakt biasa hingga mendapatkan derajat atau strata sosial yang tinggi hingga mampu setara dengan kaum bangsawan yang dulunya berkuasa disinyalir sebagai praktik pertarungan habitus para bangsawan dengan non bangsawan. Karena hadirnya habitus baru di tengah masyarakat ini yang mana masyarakat biasa mampu mendapatkan gelar kebangsawanan hanya dengan menguasa segala kapital yang ada. 


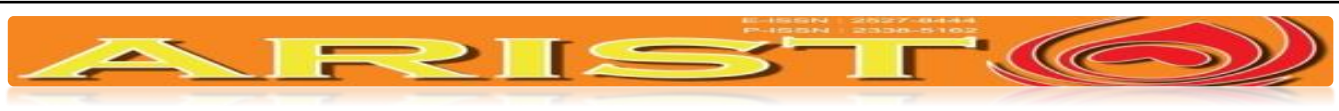

Sosial Politik Humaniora

http://journal.umpo.ac.id/index.php/aristo / aristo@umpo.ac.id

\section{Daftar Pustaka}

Abu, Abdul Rahman, dkk. 2006. Manusia Bugis (Terj). Jakarta. Nalar.

Agger, Ben.-. Teori Sosial kritis: Kritik, Penerapan dan Implikasinya. Yogyakarta. Kreasi Wacana.

Ahimsa, Heddy Shri dan Putra. 2007. Patron dan Klien di Sulawesi Selatan: Sebuah Kajian Fungsional-Struktural. Yogyakarta. Kepel Press.

Asiru, R. (2011). Kebijakan Publik Dalam Konstelasi Paradigma Pembangunan Kesejahteraan Sosial. Otoritas: Jurnal Ilmu Pemerintahan, 1(1).

Bakti, Andi Faisal. 2007. Kekuasaan Keluarga di Wajo, Sulawesi Selata dalam Politik Lokal di Indonesia, Henk Schulte Nordholt dan Gerry Van Klinken (eds). Jakarta. KITLV Press.

Densin, Norman K \& Yvonna S Lincoln (eds). 2009. Handbook Of Qualitative Research. Yogyakarta. Pustaka Pelajar.

Dwipayana, AA GN Ari. 2004. Bangsawan dan Kuasa "Kembalinya Para NIngrat di Dua Kota". Yogyakarta.IRE Press.

Field, John. 2010. Modal Sosial (terj).Yogyakarta. Kreasi Wacana.

Gaus, F Gerald \& Chandran Kukathas. 2012. Handbook Teori Politik. Bandung. Nusa Media.

Gibson, Thomas. 2005. Kekuasaan Raja, Syeikh, dan Ambtenaar: Pengetahuan Simbolik dan Kekuasaan Tradisional Makassar 1300-2000. Makassar.Ininnawa.

Haboddin, Muhtar. 2009. Karaeng dalam Pusaran Politik (Studi Kasus di Kabupaten Jeneponto). Tesis Pascasarjana Fisipol UGM.

Jenkins, Richard. 2004. Membaca Pikiran Pierre Bourdieu (terj).Yogyakarta. Kreasi Wacana.

Jones, PIP. 2003. Pengantar teori-teori Sosial-Dari Teori Fungsionalisme hingga Postmodernisme. Jakarta. Yayasan Pustaka Obor Indonesia.

Klinken, Van Gerry. 2007. Kembalinya Para Sultan: Pentas Gerakan Komunitarian dalam Politik Lokal: Adat dalam Politik Indonesia, Jamie S Davidson, David Henley, dan Sandra Moniaga (ed). Jakarta. KITLV Press.

Kymlicka, Will. 2004. Pengantar Filsafat Politik Kontemporer "Kajian Khusus atas Teori-teori Keadilan".Yogyakarta. Pustaka Pelajar. 


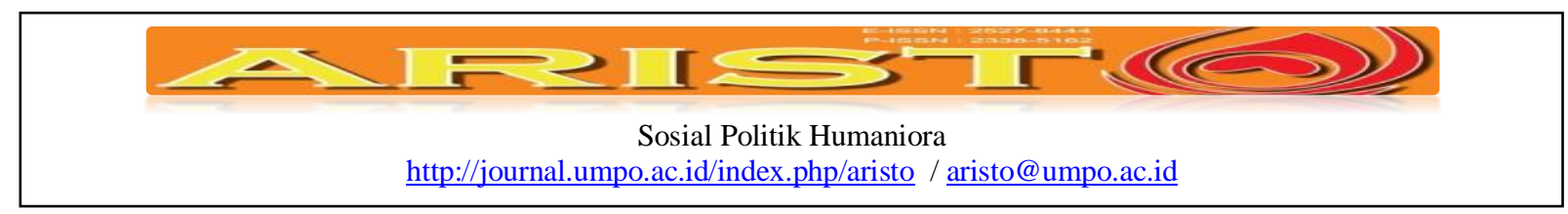

Mahfud, Choirul. 2009. 39 Tokoh Soiologi Politik Dunia. Surabaya. Jaring Pena.

Maizer, Pipit. 2009. (Habitus x Modal) + Ranah = Praktik "Pengantar Paling Komprehensif Pemikiran Pierre Bourdieu (terj). Yogyakarta.Jalasutra.

Majid, Bahri dan A. Wanua Tangke. 2012. Sejarah dan Budaya Kabupaten Pinrang. Pemerintah Kabupaten Pinrang. Media Citra Nusantara.

Mattulada. 1985. Latoa "Satu Lukisan Antropologi Politik Orang Bugis". Yogyakarta.Gadjah Mada University Press.

Muchtar, Abd Hamid, dkk. 2000. Benda-benda Peninggalan Kerajaan Sawitto. Dinas Sosial, Kebudayaan dan Pariwisata Kabupaten Pinrang.

Muhiddin, A. (2015). Penduduk dan Demokrasi (Studi Kasus Pada Pemilihan Gubernur Sulawesi Selatan Tahun 2013-2018 di Kecamatan Somba Opu Kabupaten Gowa). Otoritas: Jurnal Ilmu Pemerintahan, 5(1).

Munta, Andi Pangerang, dkk. 1989. Sejarah Lahirnya Kabupaten Daerah Tingkat II Pinrang. Pemerintah Kabupaten Pinrang.

Nehrun, I. (2016). Konflik Elit Dalam Pemilihan Walikota dan Wakil Walikota di Gorontalo Tahun 2013. Otoritas: Jurnal Ilmu Pemerintahan, 6(1), 42-49.

Poelinggomang, Edward L. 2004. Perubahan Politik dan Hubungan Kekuasaan Makassar 19061942. Yogyakarta.Ombak.

Prianto, A. L. (2011). Good Governance dan Formasi Kebijakan Publik Neo-Liberal. Otoritas: Jurnal Ilmu Pemerintahan, 1(1).

Rahim, A.Rahman. 2011. Nilai-nilai Utama Kebudayaan Bugis. Yogyakarta.Ombak.

Ritzer, George. 2011. Teori Sosilogi "Dari Sosiologi Klasik Sampai Perkembangan Terakhir Postmodern".Yogyakarta. Pustaka Pelajar.

Salim, Agus. 2006. Teori dan Paradigma Penelitian Sosial "Buku Sumber untuk Penelitian Kualitatif. Yogyakarta.Tiara Wacana.

Tim Penerjemah Ininnawa. 2009. Perkawinan Bugis "Refleksi Status Sosial dan Budaya di Baliknya" (Terj).Makassar.Ininnawa.

Usman, J. (2011). Implementasi Kebijakan Tata Kelola Pemerintahan Daerah Dengan Semangat Euforia Demokrasi Lokal. Otoritas: Jurnal Ilmu Pemerintahan, 1(1).

Yin, Robert K. 2013.Studi Kasus: Desain dan Metode (terj). Jakarta. Rajawali Pers. 


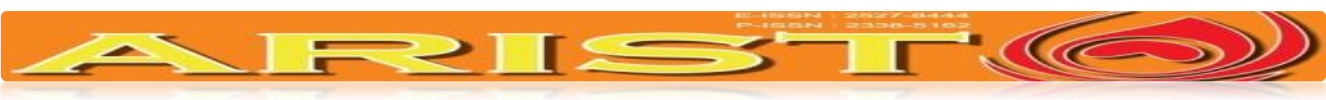

Sosial Politik Humaniora

http://journal.umpo.ac.id/index.php/aristo / aristo@umpo.ac.id

Zuhro, R Siti. 2009. Demokrasi Lokal "Peran Aktor dalam Demokratisasi”. Yogyakarta.Ombak.

Zuhro, R Siti. 2009. Demokrasi Lokal: Perubahan dan Kesinambunan Nilai-nilai Budaya Politik Lokal di Jawa Timur, Sumatera Barat, Sulawesi Selatan dan Bali. Yogyakarta.Ombak.

Media Internet

http://ajatapparengnews.com.index.php.politik.2495-aslam-pede-diusung-pks. Diakses pada tanggal 3 Agustus 2016.

http://koran.tempo.co/konten/2013/05/06/309191/Enam-Calon-Bupati-Pinrang-Diverifikasi. Diakses pada tanggal 5 Agustus 2016.

http://m.beritakotamakassar.com/index. Php/sulselbar/15196 -aslam-terima-penghargaanketahanan-pangan-.html.Diakses pada tanggal 12 Agustus 2016.

http://m.beritakotamakassar.com/index.php/politik/6253--pinrang-masih-butuh-sosok-aslampatonangi.html. Diakses pada tanggal 20 Agustus 2016.

http://makassar.tribunnews.com/2013/09/23/penetapan-bupati-pinrang-dijaga-675-aparatpolisi.htm. Diakses pada tanggal 2 September 2016.

http://www.jpnn.com.index.php.htm. Diakses pada tanggal 10 September 2016.

http://www.kabarsulawesi.com/2012/10/17/bupati-pinrang-tersandung-kasus.html Diakses pada tanggal 19 September 2016.

http://www.seputar-indonesia.com/edisi.cetak.content.htm. Diakses pada tanggal 23 September 2016. 